\title{
The relationship between working capital management policy and financial performance of companies quoted at Nairobi securities exchange, Kenya
}

\author{
Winnie Mokeira Nyabuti ${ }^{1}$, Ondiek Benedict Alala ${ }^{2}$ \\ ${ }^{1}$ School of Human Resource Development, Jomo Kenyatta University of Agriculture and Technology, Nairobi, Kenya \\ ${ }^{2}$ School of Accounting and Finance, University of Kabianga, Kericho, Kenya
}

Email address:

winmok98@gmail.com (W. M. Nyabuti),ondiekalala@yahoo.com (O. B. Alala)

\section{To cite this article:}

Winnie Mokeira Nyabuti, Ondiek Benedict Alala. The Relationship between Working Capital Management Policy and Financial Performance of Companies Quoted at Nairobi Securities Exchange, Kenya. International Journal of Economics, Finance and Management Sciences. Vol. 2, No. 3, 2014, pp. 212-219. doi: 10.11648/j.ijefm.20140203.12

\begin{abstract}
Working capital management and profitability relationship has been explored by many researchers. The study's research objectives include: To find out the relationship between working capital management policy and financial performance of companies quoted at NSE, to find out if efficient Aggressive Investment Policy has any effect on the ROA of companies quoted at NSE, to establish if Aggressive Financing Policy influences ROA of the firm at NSE, to establish the influence of working capital management policy on financial performance. The population of the study includes ten companies listed at the NSE for five years from 2008 to 2012. From the Nairobi Securities Exchange hand book (2012) sixty two firms are listed, drawn from the agriculture sector, Commercial and services, Financial and Investments, Industrial and allied Sector, Alternative Investment Market Segment. Firms quoted at NSE are preferred due to the availability and reliability of the financial statements in that they are subject to mandatory audits by recognised audit firms. The study utilised secondary data obtained from the published financial statements which were readily available at the NSE and the CMA libraries. The data collected included information on assets, liabilities and revenue levels for the period 2008 to 2012, using the annual reports published by the above mentioned companies which have been listed by NSE. Further the data was obtained from the annual handbook published by NSE.The study concludes that there is an existing relationship between working capital management policy and financial performance of companies quoted at NSE. The dependent variable which was ROA is influenced by the independent variables which are AIP and AFP by $17.2 \%$. This means that $17.2 \%$ of the changes in depended variable (ROA) can be explained by explanatory variables while $82.8 \%$ cannot be explained by explanatory variables hence error term.
\end{abstract}

Keywords: Working Capital Management Policy, Financial Performance, Aggressive Financing Policy, Aggressive Investment Policy and Return on Assets

\section{Introduction}

Working capital management is defined as the ability of an organization to fund short term assets and short term liabilities (Harris, 2005). Management of working capital needs careful attention since it plays an important role in determination of firms' financial performance, liquidity and risk as well as firms value (Smith ,1980). Greater investment in current assets leads to lower risk in settling short term obligations while leading to lower profitability. Specifically working capital investment involves a tradeoff between profitability and risk. Decisions that tend to increase profitability tend to increase risk and conversely decisions that focus on risk reduction will tend to reduce potential profitability.

Every business requires working capital for its survival. Working capital is a vital part of business investment which is essential for continuous business operations. It is required by a firm to maintain its liquidity, solvency and profitability (Mukhopadhyay, 2004). The importance of managing working capital of a business efficiently cannot be denied (Filbeck\& Krueger, 2005). Working capital management explicitly impacts both the profitability and level of desired liquidity of a business (Raheman\&Nasr, 2007). If a firm will invest heavily in working capital that is 
more than it needs, then the profits which can be generated by investing these resources in fixed or long term assets will be diminished. Moreover the firm will have to endure the cost of storing inventory for longer periods as well as the cost of handling excessive inventory (Arnold, 2008).

On the other hand, if a firm invests heavily on fixed assets to generate profits by neglecting its short-term capital needs, then it is quite possible that it may have to face bankruptcy because of insufficient funds. The profitability as well as adequate level of liquidity is required to be maintained for the survival of a business. So if a firm will not pay sufficient attention to its working capital management, then it is quite possible that the firm would have to face bankruptcy (Kargar\& Blumenthal, 1994). Shortage of working capital is normally attributed as a major cause of failure of many small businesses in various developing and developed countries ( Rafuse, (1996). Effective management of working capital decreases the need for lending funds to pay back the short term debts of the firm.

There are different approaches for the management of working capital. Two basic policies of working capital management are namely aggressive working capital management policy and conservative working capital management policy. An aggressive investment policy with high levels of fixed assets and low investment in current assets may generate more profits for a firm. However it also accompanies a risk of insufficient funds for daily operations and for payment of short term debts.

A conservative investment policy is opposite to it with less investment in fixed assets and more in current assets. For financing of working capital aggressive policy implies that current liabilities are maintained at a greater portion as compared to long term debts. High level of current liabilities requires more resources to be in liquid form to pay back debts earlier. But current pay outs bear less rate of interest and hence can cause more savings. In conservative working capital financing policy a greater portion of long term debts is used in contrast to current liabilities.

Working capital management and profitability certainly have some relation with each other. Much research work is available on this relationship though the same has not been explored in Kenya. Working capital is very important part of business activities of any firm.

The rest of the study is based on an analysis of previous literature which provides the theoretical background for the study, research methodology and sample size.

\subsection{Concept of Working Capital Management}

Firms face a number of important decisions in their operations and one of these important decisions concerns the efficient management of liquidity. According to Gupta (2002) working capital management provides the firm with information on the liquidity needed to operate efficiently. Gitman (2000) describes working capital management as the regulation, adjustment, and control of the balance of current assets and current liabilities of a firm such that maturing obligations are met, and the fixed assets are properly serviced. Pandey (2007) defines current assets as those assets which in the ordinary activities of the firm will be converted into cash within one year and current liabilities as those liabilities which are intended, at their inception to be paid in the ordinary course of business in a year.

Deloof (2003) asserts that the management of working capital necessitates short term decisions in working capital and financing of all aspects of both firm's short term assets and liabilities. He further contends that the main objective is to ascertain that the firm has the ability to continue operating with sufficient cash flow for payment of both maturing short term debt and impending operational expenses. Its thus involves multiple crucial decisions which involves managing account payables and account receivables, preserving a certain level of inventories and the investment of accessible cash.

A firm can either adopt an aggressive working capital management policy or a conservative working capital management policy. According to Nazir and Afza (2008) an aggressive Investment Policy is an approach that results in minimal level of investment in current assets versus fixed assets. This has the expectation of higher profitability but greater liquidity risk. As an alternative, a more conservative policy places a greater proportion of capital in liquid assets, but at the sacrifice of some profitability. To measure the degree of aggressiveness the current asset to total asset ratio is used, with a lower ratio meaning a relatively more aggressive policy.

According to Pandey (2007) an aggressive financing policies utilize higher levels of normally lower cost shortterm debt and less long-term capital. Although lowering capital costs, this increases the risk of a short-term liquidity problem. A more conservative policy uses higher cost capital but postpones the principal repayment of debt, or avoids it entirely by using equity. The total current liability to total asset ratio is used to measure the degree of aggressive financing policy, with a high ratio being relatively more aggressive.

\subsection{Financial Performance}

Financial performance is a subjective measure of how well a firm can use assets from its primary mode of business and generate revenues. The term is also used as a general measure of a firm's overall financial health over a given period of time and can be used to compare similar firms across the same industry or to compare industries or sectors in aggression. Financial performance can be measured by the rate of return on investment. The management of a firm working capital affects its performance. Ricci and Vito (2000) argues that the basic purpose of managing working capital is controlling of current financial resources of a firm in such a way that a balance is created between profitability of the firm and risk associated with that profitability. Holding high levels of current assets especially in form of marketable securities, 
account receivables and inventory may render the firm incapable of paying its short term obligation when they fall due. Also high levels of short liabilities increase chances of bankruptcy.

The performance of a firm can be measured in several ways. Brigham and Gapenski (1999) argue that the measures of profitability can either be book value based or market value based. They contend that accounting ratios such as Tobin's Q, ROE and ROA can be used to measure firm's performance.Falope and Ajilore (2009), Biwott (2011), Kithii (2008), Dan (2010) and Afza andNasir (2007) used (ROA). Aquino (2010) used the ratio of net income after taxes to stockholders' equity (ROE).

\subsection{Companies Quoted at NSE}

Nairobi securities Exchange is one of the most robust Capital markets in Africa NSE started in the 1920's when the country was still a British colony. NSE has undergone numerous transformations over the years to enhance its effectiveness and adapt to changes in the Economic Environment, Investors interest and leverage on technology. NSE has stringent rules and regulations on how accompany is to be enlisted on the stock market. Quoted companies are divided into different sectors, namely Agricultural, Commercial and services, Telecommunication and Technology, Automobile and Accessories, Banking, Insurance, Investment, Manufacturing and Allied, construction and Energy. Different companies Quoted at the NSE have adopted different working capital management policies; this study aims to determine how these policies have affected their financial performance.

\section{Empirical Review}

The subject of working capital management has been explored in the discipline of finance. However, very few studies have been conducted in Kenya to address whether the degree of aggressiveness or conservativeness of working capital management policies affects profitability.

Salawu (2006) investigated fifteen diverse industrial groups over an extended period to establish the relationship between aggressive and conservative working capital practices. His results strongly show that the industries had significantly different current asset management policies. Additionally the relative industry ranking of the aggressive or conservative asset policies exhibited remarkable stability over time. It is evident that there is a significant negative correlation between industry asset and liability policies. Relatively aggressive asset management seems balanced by relatively conservative working capital finance management. Furthermore he explains that a firm in deciding its working capital policies adopted in a particular industry in which it operates and a firm pursuing an aggressive working capital investment policy should match it with a conservative working capital financing policy. This is important to mitigate the risk being faced under aggressive working capital investment policies by safety involved under conservative working capital financing policy.

However, Weinraub and Visscher (1998) have discussed the issues of aggressive and conservative working capital management policies by using quarterly data for a period of 1984 to 1993 of US firms. The researchers have examined ten diverse industry groups to study the relative relationship between their aggressive, conservative working capital policies and they have concluded that the industries have distinctive and significantly different working capital management policies overtime.

Nazir and Afza (2007) studied the impact of different types of working capital management policies on financial performance of firms in different sectors in Pakistan. For this they used a sample of 263 non-financial firms belonging to 17 different sectors listed at KSE from1998 to 2003. The secondary data was collected from the financial reports of selected companies and also from the publications of State Bank of Pakistan. For the measurement of the degree of aggressiveness they used current liabilities to total assets ratio and current assets to total assets ratios. To locate the impact of these policies on the performance of firms they used Return on Equity (ROE) and Return on Assets (ROA). Results were found by using regression analysis. They found an inverse relationship between degree of aggressiveness of these policies and profitability.

Another important study confirms the results of Afza and Nazir (2007) conducted by Mian S. and Talat (2009) have shown that the negative relationship between the profitability measures of the firm and the degree of aggressiveness of working capital management policies by analyzing the 204 Pakistani firms listed under sixteen industrial groups in the Karachi Stock Exchange (KSE). The data was analyzed for the period (1998-2005). The finding says that firms with more aggressive working capital policy may not be able to generate more profit proving the negative relationship of working capital management and profitability.

Pandey and Parera (1997) provided an empirical evidence of working capital management policies and practices in the private sector manufacturing companies in Sri Lanka. The information and data for the study were gathered through questionnaires and interviews with chief financial officers of a sample of manufacturing companies listed on the Colombo Stock Exchange. They found that most companies in Sri Lanka have informal working capital policy and company size has an influence on the overall working capital policy (formal or informal) and approach (conservative, moderate or aggressive). Moreover, company profitability has an effect on the methods of working capital planning and control.

The study of Mohamad and Saad (2010) was based on secondary data of 172 firms of Malaysia. They evaluated the impact of various components of working capital on profitability and market value of the firms. The study 
covered a time span of five years from 2003 to 2007 . For this purpose they used different working capital components namely cash conversion cycles (CCC), debt ratio (DR), current assets to total assets ratio (CATAR), current liabilities to total assets ratio (CLTAR) and current ratio $(\mathrm{CR})$. To see the effect of these working capital components on financial performance they used Tobin's Q (TQ), return on invested capital (ROIC) and return on assets (ROA) as a measurement of financial performance of the selected firms. To deduce the results they used correlations and multiple regression analysis. The results showed that there exists an inverse relationship between different working capital components and performance of firms.

Sathyamoorthi (2002) focused on good corporate governance and in turn effective management of business assets. He analyzed selected Co-operatives in Botswana for the period of 1993-1997 and observed that more emphasis is given to investment in fixed assets both in management area and research. He also noted that that effective management working capital has been receiving little attention and yielding more significant results and concluded that these firms followed an aggressive approach during the whole four-year study period.

Ochieng (2006) on his studies on the effects of the relationship between working capital of firms listed at the Nairobi Stock Exchange and the economic activity in Kenya, finds that the liquidity of the firms, measured by the current and quick ratios, increases with economic expansion and decreases during economic showdowns. He however says that the liquidity positions reacted differently to various economic indicators such as inflation and lending rates. The study showed that inflation was not significant in a massive $83 \%$ of the firms. It is however found that lending rates indeed affect the amount of working capital policy of a firm.

Apuoyo (2010) on his study on the relationship between working capital management policies and profitability for companies quoted at the NSE finds that the financial and investment sector has been able to achieve high scores on the various components of working capital and this has positive impact on profitability.

Biwott (2011) and Deloof (2003), found a strong negative relationship between the measures of working capital management including the average collection period, inventory turnover in days, the average payment period and cash conversion cycle with corporate profitability.

Gitman (2000) on his study working capital management is concerned with the problems that arise in attempting to manage current assets, the current liabilities and the relationship that exists between them. Pandey (2007) defines current assets as those assets which in the ordinary course of business can be, or will be converted into cash within one year without undergoing a diminution in value and without disrupting the operation of the firms. Examples are cash, marketable securities, account receivables and inventory. On the other hand, current liabilities are those liabilities which are intended, at their inception to be paid in the ordinary course of business in a year out of current assets or earnings of the concern. The basic current liabilities are account payables, bills payable, bank overdraft and outstanding expenses.

Van -Horne and Wachowicz (2004) posits that when a business entity takes the decisions regarding its current assets and liabilities then it can be termed as working capital management. He defines working capital management as an accounting approach that emphasize on maintaining proper levels of both current assets and current liabilities. It provides enough cash that meets short-term obligations.

Lamberson (1995) observes that working capital management has become one of the most important issues in organizations where many financial executives strive to identify the basic working capital drivers and the appropriate level of working capital. Efficient management of working capital is a fundamental part of the overall corporate strategy to create the shareholders' value. $\mathrm{He}$ suggests that managers should strive to achieve an optimal or efficient level of working capital.

Raheman\& Nasr (2007) emphasizes the importance of working capital that every business requires working capital for its survival. Working capital is a vital part of business investment which is essential for continuous business operations. It is required by a firm to maintain its liquidity, solvency and profitability. Filbeck and Krueger (2005) assert that the importance of managing working capital of a business efficiently cannot be denied and thus needs to be accorded the importance it deserves.

Arnold (2008) observes that working capital management explicitly impacts both the profitability and level of desired liquidity of a business. If a firm will invest heavily in working capital, that is, more than its needs, then the profits which can be generated by investing these resources in fixed or long term assets will be diminished. Moreover the firm will have to endure the cost of storing inventory for longer periods as well as the cost of handling excessive inventory.

Arnold (2008) further argues that if a firm will invest heavily in fixed assets to generate profits by neglecting its short-term capital needs then it is quite possible that it may have to face bankruptcy because of insufficient funds. The profitability as well as adequate level of liquidity is required to be maintained for the survival of a business, so if a firm will not pay sufficient attention to its working capital management, then it is quite possible that the firm would have to face bankruptcy.

\section{Conceptual Framework}

Figure 1 below presents schematic conceptual framework of the relationship between working

Capital management policies and financial performance of firms. 


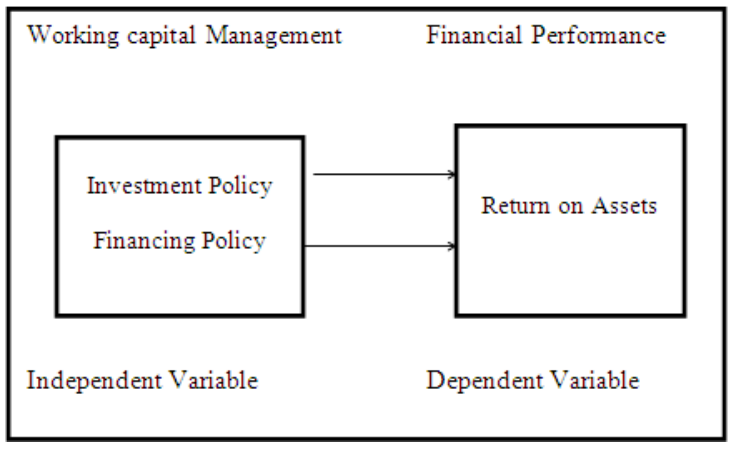

Figure 1. Conceptual framework

\section{Research Objectives}

\subsection{General Objective}

1. To find out the relationship between working capital management policy and financial performance of companies quoted at NSE

\subsection{Specific Objectives}

1. To determine the effect of Aggressive Investment Policy on the ROA of companies quoted at NSE.

2. To establish if Aggressive Financing Policy influences ROA of the firm at NSE.

3. To establish the influence of working capital management policy on financial performance.

\subsection{Research Questions}

1. What is the relationship between working capital management policy and financial performance of companies quoted at NSE?

2. Does Aggressive Investment Policy have any effect on the ROA of firms quoted at NSE?

3. Does Aggressive Financing Policy influence ROA of the firm at NSE?

4. Does working capital management policy influence financial performance?

\section{Data Analysis}

The study sought to establish the relationship between the degree of working capital management policy and financial performance for firms listed at the NSE. The independent variable of the study was working capital management policy. The working capital management policy has two facets, i.e. investment and financing policy. To measure the degree of aggressiveness of working capital investment policy (AIP) the following ratio was used;

$$
\text { AIP }=\text { Total Current Assets (TCA)/ Total Assets (TA) }
$$

The degree of aggressiveness in financing policy (AFP) will be measured by the total current liabilities to total assets ratio. Thus;

\section{$\mathrm{AFP}=$ Total Current Liabilities (TCL) $/$ Total Assets (TA)}

The study employs Return on Asset (ROA) the dependent variable and measures of profitability. The debt ratio and firm size are used as control variables and will be measured by the debt ratio and natural log of asset respectively. Therefore, the model of the study is as follows:

$$
\mathrm{ROA}_{\mathrm{it}}=\mathrm{a}+\mathrm{a}_{1} \mathrm{x}_{1}+\mathrm{a}_{2} \mathrm{x}_{2}+\varepsilon_{\mathrm{it}}
$$

Where;

$\mathrm{a}$ is the constant

$a_{1} \ldots a_{2}$ are coefficients to explanatory variables

$\mathrm{x}_{1}(\mathrm{AIP})=$ Total Current Assets (TCA)/ Total Assets (TA)

$\mathrm{x}_{2}(\mathrm{AFP})=$ Total Current Liabilities $(\mathrm{TCL}) /$ Total Assets

(TA)

$\varepsilon_{\mathrm{it}}=$ Error Term

\subsection{Descriptive Statistics}

The descriptive statistics for the three variables have been obtained for empirical investigation and are presented in the Table 4.2.

Table 1. Descriptive Statistics

\begin{tabular}{llllll}
\hline & N & Minimum & Maximum & Mean & $\begin{array}{l}\text { Std. } \\
\text { Deviation }\end{array}$ \\
\hline ROA & 47 & .000005 & .003217 & .00043211 & .000688808 \\
AIP & 50 & .500000 & .999765 & .89616444 & .200217542 \\
AFP & 50 & .117789 & 3.123740 & .81930908 & .549544458 \\
Valid N & 47 & & & & \\
(listwise) & & & & & \\
\hline
\end{tabular}

From table 1 on descriptive statistics provides a summary of dependent and independent variables for 10 companies quoted at NSE for a period of five years from 2008 to 2012. It shows the number of observations of all variables, their average values and their standard deviation. It shows the minimum and maximum values as well which can be attained by these variables. The descriptive statistics show that all the variables have 47 observations. All the variables have a positive mean this shows that the companies at NSE have good performance. The dependent variable return on assets has the average value of 0.00043211 It has a minimum value of 0.00005 and a maximum value of 0.003217 . The standard deviation for return on assets was 0.000688 . To check the working capital investment policy of these companies, current assets to total assets ratio (AIP) is included, it has an average value of 0.896164 with a standard deviation of 0.200217 . Minimum value of AFP is 0.117789 and its maximum value was 3.12. AFP has the highest standard deviation followed by AIP and then ROA.

Table 2. Correlations

\begin{tabular}{lllll}
\hline & & ROA & AIP & AFP \\
\hline \multirow{3}{*}{ ROA } & Pearson Correlation & 1 & .277 & $.372^{* *}$ \\
& Sig. (2-tailed) & & .057 & .009 \\
& $\mathrm{~N}$ & 48 & 48 & 48 \\
\hline
\end{tabular}




\begin{tabular}{lllll}
\hline & & ROA & AIP & AFP \\
\hline \multirow{4}{*}{ AIP } & Pearson Correlation & .277 & 1 & $.352^{*}$ \\
& Sig. (2-tailed) & .057 & & .012 \\
& $\mathrm{~N}$ & 48 & 50 & 50 \\
\multirow{4}{*}{ AFP } & Pearson Correlation & $.372^{* *}$ & $.352^{*}$ & 1 \\
& Sig. (2-tailed) & .009 & .012 & \\
& $\mathrm{~N}$ & 48 & 50 & 50 \\
\hline
\end{tabular}

**. Correlation is significant at the 0.01 level (2-tailed).

*. Correlation is significant at the 0.05 level (2-tailed).

From table 2 provides the Pearson's Correlation matrix for all the variables used in the analysis coefficient explains the relationship between two variables. It shows change in one variable because of any change in other variable. This analysis helps to locate the relationship that exists among the independent or explanatory variables there was positive correlation between ROA and AIP 0.277.ROA has significant positive correlation with AFP $0.372^{* *}$. There was significant positive correlation between AIP and AFP

Table 3. Model Summary

\begin{tabular}{lllll}
\hline Model & $\mathbf{R}$ & $\begin{array}{l}\mathbf{R} \\
\text { Square }\end{array}$ & $\begin{array}{l}\text { Adjusted R } \\
\text { Square }\end{array}$ & $\begin{array}{l}\text { Std. Error of the } \\
\text { Estimate }\end{array}$ \\
\hline 1 & $.414^{\mathrm{a}}$ & .172 & .134 & .000641023 \\
a. Predictors: (Constant), AFP, AIP & \\
\hline
\end{tabular}

Dependent variable: ROA

From table 3 model summary the value of $\mathrm{R}$ square is 0.172 this implies that $17.2 \%$ of variance in the independent variables can be accounted in the dependent variable ROA. The standard error for the estimates is 0.000641023 and adjusted R square is 0.134 . This model is good fit as F-statistics is significant. This means that $17.2 \%$ of the changes in depended variables can be explained by explanatory variables while $82.8 \%$ cannot be explained by explanatory variables hence error term.

\section{Conclusions of the Study}

Based on the research questions of the paper it answers them as follows:

1. What is the relationship between working capital management policy and financial performance of companies quoted at NSE?

The study concludes that there is an existing relationship between working capital management policy and financial performance of companies quoted at NSE. The dependent variable which is ROA is influenced by the independent variables which were AIP and AFP by $17.2 \%$. This means that $17.2 \%$ of the changes in dependent variable (ROA) can be explained by explanatory variables while $82.8 \%$ cannot be explained by explanatory variables hence error term. The model therefore is as below:

$$
\mathrm{ROA}_{\text {it }}=\mathrm{a}+\mathrm{a}_{1} \mathrm{x}_{1}+\mathrm{a}_{2} \mathrm{x}_{2}+\varepsilon_{\mathrm{it}}
$$

$$
\mathrm{ROA}_{\text {it }}=\mathrm{a}+0.174 \mathrm{a}_{1}+0.32 \mathrm{a}_{2}+0.828
$$

2. Does Aggressive Investment Policy have any effect on the ROA of firms quoted at NSE?

The study also concludes that efficient working capital management has a positive effect on the financial performance of the company. The dependent variable which is ROA is influenced by the independent variables which were AIP and AFP by $17.2 \%$. This means that $17.2 \%$ of the changes in dependent variable (ROA) can be explained by explanatory variables while $82.8 \%$ cannot be explained by explanatory variables hence error term. The Beta-coefficient of current assets to total assets ratio is 0.174 which shows that if there is an increase of 1 unit in AIP then it causes an increase of 0.174 units in ROA. So, there is positive relationship between AIP and ROA.

3. Does Aggressive Financing Policy influence ROA of the firm at NSE?

The study also concludes that efficient working capital management has a positive effect on the financial performance of the company. The dependent variable which is ROA is influenced by the independent variables which were AIP and AFP by $17.2 \%$. This means that $17.2 \%$ of the changes in dependent variable (ROA) can be explained by explanatory variables while $82.8 \%$ cannot be explained by explanatory variables hence error term. Similarly the Beta-coefficient of current liabilities to total assets ratio is 0.320 which shows that if there is an increase of 1 unit in AFP then it causes an increase of 0.320 units in ROA. So, there is a positive relationship between AFP and ROA.

4. Does working capital management policy influence financial performance?

The study concludes that working capital management policy influence financial performance. The independent variables which are investment policy and financing policy influence ROA which is the financial performance. The Beta-coefficient of current assets to total assets ratio is 0.174 which shows that if there is an increase of 1 unit in AIP then it causes an increase of 0.174 units in ROA. So, there is positive relationship between them. Similarly the Beta-coefficient of current liabilities to total assets ratio is 0.320 which shows that if there is an increase of 1 unit in AFP then it causes an increase of 0.320 units in ROA. The dependent variable which is ROA is influenced by the independent variables which were AIP and AFP by $17.2 \%$. This means that $17.2 \%$ of the changes in dependent variable (ROA) can be explained by explanatory variables while $82.8 \%$ cannot be explained by explanatory variables hence error term. 
The study recommends that if proper policies of formulating strategies on working capital management are used, their impact on profitability will improve especially in developing countries like Kenya.

\section{References}

[1] Abor, J. (2005). The Effect of Capital Structure on Profitability: An Empirical Analysis of Listed Firms in Ghana. Journal of Risk Finance, Vol. 6,438-47.

[2] Apuoyo B.O. (2010). The Relationship between Working Capital Management Policies and Profitability for Companies Quoted at the NSE, Unpublished MBA Project, University of Nairobi.

[3] Arnold, G. (2008). Corporate financial management.Pearson education limited, $4^{\text {th }}$ edition.

[4] Baumol, W.J. (1952). Baumol's Model for Managing Inventories: Journal of Economics, Vol. 52(4).

[5] Biwott R.K (2011). The Relationship between Working Capital Management Practices and Profitability of Companies Quoted at the Nairobi Stock Exchange, Unpublished MBA Project, University of Nairobi

[6] Brigham E.F. \&Gapenski L.C. (2004).Intermediate Financial Management, $8^{\text {th }}$ ed, Dryden Press.

[7] Chiou et al (2006).The Determinants of Working Capital Management.Journal of American Academy of Business, vol 10, 149-155.Conservative Working Capital Policies, Journal of Financial and Strategic Decision, vol 12,143-57.

[8] DeAngeloH.andR.Musulis(1980),OptimalCapitalStructurea ndCorporateandPersonalTaxation,Journal of Financial Economics, 8 , 3-29

[9] Eljelly A.M.A (2004) "Liquidity-Profitability trade off an Empirical Investigations in an Emerging Market" International journal of commerce and management vol 14 No 2 ,PP 48-61

[10] Fisher I. (1911). The Equation of Exchange.American Economic Review.Vol 10, 1896-1910.

[11] Friedman M. (1956). The Quantity Theory of Money: A Restatement.The Optimum Quantity ofMoney,51-67

[12] Gill (2010).The Relationship between Working Capital Management and Profitability: Evidence from the United States.Business and Economics Journal, Vol. 11.

[13] Gupta C.P. (2002) Working Capital Performance of Corporate India: An Empirical Survey for the Year 20002001. Management and Accounting Research, January-June, 43-67.

[14] Harris, A. (2005) Working Capital Management. Difficult but Rewarding. Financial Executive 21(4);52-53

[15] Jensen M.C. (1977).The Agency Costs of Free Cash Flows, Corporate Finance and Takeover, Journal of American Economic Review, 323-329.

[16] Keynes J.M. (1936). The General Theory of Employment, Interest and Money, Harcourt, Brace and Company, New York.
[17] Kithii J.N. (2008). The Relationship between Working Capital Management and Profitability of Companies listed on the Nairobi Stock Exchange. Unpublished MBA Project, University of Nairobi.

[18] Lamberson M. (1995). Changes in Working Capital of Small Firms in Relation to Changes in Economic Activity.MidAmerican Journal of Business 10(2): 45-50.

[19] Mathuva D. (2009).The Influence of Working Capital Management Components on Corporate Profitability: A Survey on Kenyan Listed Firms. Research Journal of Business Management, vol 3 (2), 11-18

[20] Mian S.N \&Talat A. (2009).Impact of Aggressive Working Capital Management Policy on Firms Profitability.TheIUPJournal of Applied Finance, Vol. 15, No.8,2009 12: 112-124

[21] Mukhopadhyay, D. (2004). Working capital management in heavy engineering firms- A case study. Management Accountant-Calcutta-,39,317-323.

[22] Myers S.C. (1984). TheCapitalStructurePuzzle. Journal of Finance, 39, 575-592

[23] Nazir M. \&Afza T. (2009).The Impact of Aggressive Working Capital Management Policy on Firm's profitability, The IUP Journal of Applied Finance, Vol. 15.

[24] Nyakundi M. (2003).The Working Capital Management Policies Among Public Companies in Kenya, Unpublished MBA Project, University of Nairobi.

[25] Ochieng A. J. (2006).Relationship Between Working Capital Of Firms Listed on The Nairobi Stocks Exchange and Economic Activities In Kenya, Unpublished MBA Project, University of Nairobi.

[26] Pandey, I.M. (2007), Financial Management, Ninth Edition, New Delhi; Vikas Publishers.

[27] Penrose E.T. (1959). The theory of the Growth of the firm, New York, Wiley.

[28] Rehman A. \&Nazir M. (2006).Working Capital Management and Profitability: Case of Pakistani Firms, Unpublished Dissertation, COMSATS Institute of Information Technology (CIIT), Islamabad, Pakistan.

[29] Ricci, C. \& Vito N. (2000).International Working Capital Practices in the UK.European Financial Management, 6(1), 69-84.

[30] Richards V.D. \& Laughlin E.J. (1980).A Cash Conversion Cycle Approach to Liquidity Analysis, Financial Management Journal, vol 9 (1), 32-38.

[31] Salawu R.O. (2006). Industry Practice and Aggressive Conservative Working Capital Policies in Nigeria.EuropeanJournalofScientificResearchvol.13No.3(20 06), pp. 294-304

[32] Sathamoorthi C.R. (2002). The Management of Working Capital in selected co-operatives in Botswana. Finance India Dehli16(3), 1015-1034.

[33] Shin, H.H. \&Soenen, L. (1998). Efficiency of Working Capital Management and Corporate Profitability, Financial Practice and Education, Vol. 8 (2), 37-45. 
[34] Smith K. (1980) Profitability versus Liquidity Tradeoffs in Working Capital Management, in Reading on the Management of Working Capital. New York: St. Paul, West Publishing Company.

[35] Soenen L. A. (1993). Cash Conversion Cycle and Corporate Profitability.Journal of Cash Management 13(4): 53-58
[36] Titman S. \&Wessels R. (1988). The Determinants of Capital Structure Choice. Journal of Finance, Vol 43, 1-19.

[37] Van Horne J.C \&Wachowicz J.M (2000).Fundamentals of Financial Management. $11^{\text {th }}$ ED Prentice Hall Inc

[38] Weinraub H. J. \&Visscher S. (1998).Industry Practice Relating to Aggressive 